\title{
Sinergisitas Lembaga Perkreditan Desa (LPD) \\ Dalam Membangun Perekonomian Masyarakat \\ by
}

\section{Gusti Ngurah Putra Suryanata}

Universitas Pendidikan Nasional

ngurahputrasuryanata@undiknas.ac.id

\begin{abstract}
This study aims to explain about 1) the synergy of Village Credit Union (Lembaga perkreditan Desa - LPD) in Kedonganan Village in developing the social welfare and 2) to maintain the competitive advantage of LPD in Kedonganan Village in developing the social welfare. The background theory that is used in this study are Synergy Theory and Social Capital Theory. This study used qualitative method with case study approach. The data in this study is collected by in-depth interview and unstructured interview. The result of this study shows that LPD in Kedonganan Village have done a synergy with the Kedonganan's village boards and the society to build social welfare. When doing the synergy, they use Social Capital approach, which are building a networking with micro and macro financial institutions around Kedonganan Village with Dharma (Kindness) and Catur Purusa Artha (Trust) as the basic principals. The administrator of the LPD also creating trust in society by using Tri Hita Karana as the concept. The rule that is used in maintaining LPD also referring to common law that is called as awig-awig or perarem which has become a mutual agreement among Kedonganan Village society. To maintain the competitive advantage of LPD in developing social welfare, the manager or administrator of LPD should care about internal and external factors.
\end{abstract}

Keywords: Sinergy, Social Capital 


\begin{abstract}
ABSTRAK
Penelitian ini bertujuan untuk menjelaskan 1) Sinergisitas LPD Desa Adat Kedonganan dalam membangun perekonomian masyarakat dan 2) Mempertahankan Keunggulan Kompetitif LPD Desa Adat Kedonganan dalam membangun perekonomian masyarakat. Teori yang digunakan dalam penelitian ini adalah teori sinergi dan teori modal sosial. Penelitian ini menggunakan metode kualitatif pendekatan studi kasus. Data dalam penelitian ini akan didapat melalui wawancara yang mendalam atau wawancara tak berstruktur. Hasil penelitian menunjukkan bahwa LPD Desa Adat Kedonganan melakukan sinergisitas dengan Prajuru Desa Adat Kedonganan dan Masyarakat Desa Adat Kedonganan secara bersama-sama membangun perekonomian masyarakat Desa Kedonganan. Dalam melaksanakan sinergisitas menggunakan pendekatan modal sosial diantaranya : membangun jaringan dengan lembaga keuangan mikro dan makro yang ada di lingkungan Desa Kedonganan yang berlandaskan pada Dharma atau kebaikan konsep Catur Purusa Artha; menjaga kepercayaan, dimana pengelola LPD Desa Adat Kedonganan menciptakan kepercayaan terhadap masyarakat Desa Kedonganan menggunakan ajaran Tri Hita Karana sebagai konsepnya; norma-norma yang digunakan dalam tata kelola LPD Desa Adat Kedonganan mengacu pada hukum adat yaitu awig-awig atau perarem yang sudah menjadi kesepakatan bersama masyarakat adat Desa Kedonganan. Untuk mempertahankan keungunan kompetitif LPD Desa Adat Kedonganan dalam meningkatkan perekonomian masyarakat pihak pengelola LPD Desa Adat Kedonganan tetap memperhatikan faktor internal atas dan eksternal.
\end{abstract}

Kata Kunci: Sinergisitas, modal sosial. 


\section{PENDAHULUAN}

Lembaga Perkreditan Desa (LPD) sebagai suatu Lembaga Keuangan Mikro (LKM) sehingga LPD didirikan khusus untuk kepentingan demi mensejahterakan masyarakat desa pakraman/adat, dalam kegiatannya hanya melayani masyarakat desa pakraman saja, LPD tidak melayani masyarakat diluar dari wilayah desa pakraman/adat tempat LPD tersebut beroperasi. Karena itu LPD dikatakan sebagai lembaga keuangan yang memiliki sifat khusus.

LPD Desa Adat Kedonganan yang didirikan pada 9 September 1990 atau sekarang genap berusia 26 tahun. Dalam menjalankan usaha LPD Desa Adat Kedonganan yang dilandasi dengan konsep Catur Purusa Artha yaitu Dharma, Artha, Kama dan Moksa. Kalau dilihat makna Dharma yang berarti kebaikan. Kebaikan dimaksud disini seperti cara berfikir, perilaku, sampai pada tata kelola manajemen Lembaga Perkreditan Desa (LPD) yang mampu bertahan sampai saat ini. Usaha dijalankan dengan dasar Dharma atau baik niscaya akan mempermudah cara kerja atau apa yang dicita-citakan akan mudah tercapai. Kegiatan usaha LPD merupakan kegiatan usaha yang disamping bersifat sosial-ekonomi juga bersifat kultural-religius. Sehingga kegiatan usaha LPD memiliki tujuan yang sejalan dengan tujuan Agama Hindu. Tujuan agama Hindu yang dirumuskan sejak Weda mulai diwahyukan adalah "Moksartham Jagadhitaya ca iti Dharma", yang artinya bahwa agama (dharma) bertujuan untuk mencapai kebahagiaan rohani dan kesejahteraan hidup jasmani atau kebahagiaan secara lahir dan bathin. Konsep Catur Purusa Artha yang dijadikan dasar Lembaga Perkreditan Desa (LPD) Kedonganan dalam menjalankan kegiatan usahanya bersumber atau didasari oleh hukum Agama Hindu yang bersumber dari Kitab Suci Weda. (Pancadana dan Oka, 2013)

Anggota yang memanfaatkan jasa keuangan LPD Desa Adat Kedonganan adalah masyarakat Desa Adat Kedonganan maupun masyarakat pendatang yang telah berdomisili di lingkungan Desa Adat Kedonganan. Masyarakat yang tumbuh di Desa Kedonganan ini tergolong kedalam masyarakat yang heterogen. Desa Kedonganan termasuk ke dalam kawasan desa pesisir, dimana sisi kiri dan kanan desa ini adalah laut. Hal ini yang menyebabkan sebagian besar penduduknya pada mulanya bergerak di sektor perikanan dan kelautan. Sekitar 90\% warga Kedonganan berprofesi sebagai nelayan dan sebagian lagi berprofesi sebagai pedagang atau pun buruh. Perikanan dan kelautan secara umum memang menjadi ikon Kedonganan. Bahkan, Kedonganan hingga kini menjadi salah satu sentra usaha perikanan dan kelautan terbesar di Bali. Kehadiran Tempat Pelelangan Ikan (TPI) Kedonganan menunjukkan 
Kedonganan memang memegang peranan penting dalam bidang perikanan (Situs LPD Kedonganan, diakses 24 Oktober 2016).

LPD Desa Adat Kedonganan berdiri yang dilandasi atas dasar ketidakpercayaan masyarakat terhadap pengelola jasa keuangan desa dimana terjadinya ketidakberesan pengelolaan KUD Kedonganan sampai bangkrut, banyak masyarakat yang mengalami kerugian pada sektor finansial. Beberapa tahun setelah bangkrutnya KUD Kedonganan, berdiri LPD Desa Adat Kedonganan. Membangun kembali kepercayaan masyarakat akan lembaga jasa keuangan khususnya LPD Desa Adat Kedonganan yang dilatarbelakangi ketidakpercayaan masyarakat dan dilihat dari demografi masyarakatnya mayoritas bekerja sebagai pelaut bukan orang kantoran, hal ini menjadi tantangan yang serius bagi manajemen LPD Kedonganan khususnya kepala LPD. Sisi lain berdirinya LPD Desa Adat Kedonganan diharapkan mampu menunjang sektor ekonomi kerakyatan, serta mampu memberi bantuan dalam memelihara Tri Kahyangan sesuai dengan Peraturan Daerah Provinsi Bali No. 4 Tahun 2012 yang salah satunya menjelaskan bahwa keuntungan bersih LPD pada akhir tahun pembukuan sekitar $20 \%$ untuk dana pembangunan desa dan $5 \%$ untuk dana sosial.

Melihat fenomena tersebut peneliti tertarik untuk mengkaji atau mengetahui bagaimana sinergisitas LPD dalam membangun perekonomian masyarakat adat di Desa Adat Kedonganan Badung?

\section{TUJUAN PENELITIAN}

Penelitian ini bertujuan untuk menjelaskan :

1) Sinergisitas LPD Desa Adat Kedonganan dalam membangun perekonomian masyarakat.

2) Mempertahankan Keunggulan Kompetitif LPD Desa Adat Kedonganan dalam membangun perekonomian masyarakat.

\section{TINJAUAN TEORITIS}

\section{Sinergi}

Ansoff (1968) dalam Sulasmi (2006:223) mengadopsi konsep sinergi dalam lingkup kebijakan bisnis dan didefinisikan sebagai suatu efek yang dapat menghasilkan suatu hasil yang diperoleh dari kombinasi berbagai sumber daya organisasi, yang nilainya lebih besar dari jumlah nilai masing-masing bagiannya. Sedangkan Hampden-Turner (1990) menyatakan bahwa aktivitas sinergi merupakan suatu proses yang melibatkan berbagai aktivitas, yang 
berjalan bersama sehingga menciptakan sesuatu yang baru. Sinergi merupakan hasil dari suatu relasi dialogik antara berbagai sumber pengetahuan yang berbeda, dan merupakan suatu proses yang mengakumulasikan berbagai macam pengetahuan. Hartanto (1996) menyatakan sinergi adalah suatu gagasan baru, yang terbentuk dari berbagai macam gagasan yang diajukan oleh banyak pihak hingga menghasilkan suatu gagasan baru, yang dilandasi oleh pola pikir atau konsep yang baru.

Dalam setiap kelompok kerja dalam organisasi, kualitas sinergi yang merupakan sinergi efektif pada hakekatnya adalah hasil dari suatu proses perpaduan dari cara-cara bagaimana mengatasi masalah dan perpaduan gagasan yang dijalankan oleh pihak-pihak yang saling percaya dan bersikap saling mendukung menghasilkan suatu gagasan baru yang benar-benar memberikan kepuasan secara intrinsik bagi semua belah pihak. Menurut Quigley (1993) menyatakan kualitas sinergi merupakan hasil kerjasama dalam kelompok, yang intinya didukung oleh perilaku kerjasama di antara anggotanya. Kerjasama yang dimaksud adalah kerjasama yang kritikal, di mana seluruh anggota kelompok berpartisipasi dan berkolaborasi dalam organisasi yang berbudaya sinergistik untuk memenuhi tuntutan organisasi.

\section{Modal Sosial}

Modal sosial yang dikemukakan oleh Putnam (1993) menyatakan bahwa penampilan organisasi sosial, seperti kepercayaan, resiproritas, jaringan yang dapat memperbaiki efisiensi masyarakat dengan memfasilitasi adanya koordinasi dan kerjasama bagi keuntungan bersama. Sedangkan Coleman (1988), mendefinisikan modal sosial berdasarkan fungsinya. Modal sosial merupakan entitas majemuk yang mencakup beberapa aspek dari struktur sosial, dan memfasilitasi tindakan tertentu dari pelaku, baik individu maupun perusahaan di dalam struktur tersebut.

Fukuyama (1995) mengatakan bahwa modal sosial adalah kemampuan yang timbul akibat dari adanya kepercayaan, dalam sebuah komunitas masyarakat. Lebih lanjut dalam karyanya yang berjudul : Trust, The Sosial Virtues and TheCreation of Prosperity. Fukuyama (1999) dalam karyanya dengan tegas mengatakan bahwa belum tentu norma-norna dan nilainilai bersama yang dipedomani tersebut sebagai acuan sikap, tingkah-laku, dan bertindak tersebut otomatis menjadi modal sosial, tetapi kadang kala hanya sebagai norma-norma dan nilai-nilai bersama yang dibangkitkan oleh rasa saling percaya. Artinya, rasa saling percaya ini adalah merupakan harapan-harapan akan terjadinya keteraturan-keteraturan, kejujuran dan 
perilaku kooperatif yang muncul dari dalam sebuah komunitas masyarakat yang perilaku sehari-harinya didasari oleh norma-norma atau nilai-nilai yang dianut bersama oleh para anggotanya. Norma-norma tersebut dapat berisi pernyataan-pernyataan yang berisi nilai-nilai luhur, kebajikan dan keadilan.

Dari beberapa pendapat diatas dapat dinyatakan bahwa modal sosial memberikan penekanan pada kebersamaan masyarakat untuk mencapai tujuan dalam rangka memperbaiki kualitas hidupnya dan senantiasa melakukan perubahan dan penyesuaian secara berkesinambungan. Menurut Ridell (1997), mengatakan terdapat tiga parameter modal sosial, yaitu : (1) jaringan, (2) kepercayaan, dan (3) norma-norma.

\section{Lingkungan Organisasi}

Menurut Suryanata (2009:20) menyatakan bahwa analisis lingkungan merupakan salah satu unsur penting proses manajemen strategi, sebab analisis lingkungan menghasilkan sejumlah informasi yang diperlukan untuk menilai dan melihat masa depan organisasi atau perusahaan. Tujuan dari analisis lingkungan adalah agar organisasi atau perusahaan mampu memanfaatkan informasi perubahan untuk mendapatkan keunggulan kompetitifnya di masa depan. Wheleen dan Hunger (2001:9) dalam Suryanata (2009:19) lingkungan organiasi dibedakan atas lingkungan internal (Internal Environment) dan lingkungan eksternal (External

\section{Environment)}

Lingkungan internal yaitu kekuatan (strength) dan kelemahan (weaknesses) yang juga akan menentukan apakah perusahaan mampu mengambil keuntungan dari peluang-peluang yang ada sambil menghindari ancaman-ancaman (Wheelen dan Hunger, 2001 :155). Lingkungan internal terdiri dari struktur (structure), budaya (culture), sumber daya (resources) (Wheelen dan Hunger, 2001: 10).

Menurut Atmosoeprapto, dalam Hessel Nogi (2005: 181) mengemukakan bahwa kinerja organisasi dipengaruhi oleh faktor internal, yang terdiri dari :

1) Tujuan organisasi, yaitu apa yang ingin dicapai dan apa yang ingin diproduksi oleh suatu organisasi.

2) Struktur organisasi, sebagai hasil desain antara fungsi yang akan dijalankan oleh unit organisasi dengan struktur formal yang ada.

3) Sumber Daya manusia, yaitu kualitas dan pengelolaan anggota organisasi sebagai penggerak jalanya organisasi secara keseluruhan. 
4) Budaya Organisasi, yaitu gaya dan identitas suatu organisasi dalam pola kerja yang baku dan menjadi citra organisasi yang bersangkutan.

Mulyadi (2001; 80) dan Peter Wright (1996;23) dalam Suryanata (2009:35) membagi lingkungan eksternal atau makro atas empat kekuatan pokok : politik dan hukum, ekonomi, teknologi dan sosial.

\section{METODOLOGI}

Penelitian ini menggunakan metode kualitatif sebagaimana diungkapkan oleh Mulyana (2010:150) yang menyatakan bahwa :

"Metode penelitian kualitatif dalam arti penelitian kualitatif tidak mengandalkan bukti berdasarkan logika matematis, prinsip angka, atau metode statistik. Penelitian kualitatif bertujuan mempertahankan bentuk dan isi perilaku manusia dan menganalisis kualitaskualitasnya, alih-alih mengubah menjadi entitas-entitas kuantitatif".

Pendekatan yang digunakan dalam penelitian adalah studi kasus. Teknik pemilih informan dilakukan dengan cara teknik bola salju (snowball sampling). Data dalam penelitian ini akan didapat melalui wawancara pada narasumber yang sesuai dengan kriteria penelitian, yaitu Ketua LPD Kedonganan, Prajuru Desa Adat Kedonganan yang sekaligus sebagai pengawas dan masyarakat Desa Kedonganan. Teknik pengumpulan data dengan wawancara yang mendalam atau wawancara tak berstruktur. Wawancara tak berstruktur mirip dengan percakapan informal (Mulyana, 2001: 181). Teknik wawancara ini mengimplikasi pertanyaan terbuka dan mengarah pada cerita dari sudut pandang informan. Setelah data diperoleh akan ditelaah dengan menggunakan analisis tematik untuk mengidentifikasi pola melalui kesamaan dan perbedaan dalam penjelasannya yang diusung oleh Braun dan Clarke (2006).

\section{PEMBAHASAN}

Dari temuan dan hasil wawancara dengan informan penelitian tentang sinergisitas LPD Desa Adat Kedonganan dalam membangun perekonomian masyarakat dan mempertahankan keunggulan kompetitif LPD Desa Adat Kedonganan akan diuraikan pada analisis berikut ini. 


\section{A. Sinergisitasi LPD Desa Adat Kedonganan Dalam Meningkatkan Perekonomian} Masyarakat

Berdasarkan hasil atau temuan penelitian, sinergisitas LPD Desa Adat Kedonganan dalam meningkatkan perekonomian masyarakat dianalisis dengan teori modal sosial antara lain:

\section{Jaringan LPD Desa Adat Kedonganan}

Keberhasilan sebuah organisasi tidak terlepas dari peran serta semua unsur yang ada dilingkungan organisasi tersebut. Sejak awal berdirinya LPD Desa Adat Kedonganan pihak pimpinan telah melakukan proses kerjasama atau membangun jaringan, hal yang paling terdekat dengan menjadikan masyarakat dilingkungan desa Adat Kedonganan dan prajuru atau pimpinan adat yang sekaligus sebagai pengawas LPD Desa Adat Kedonganan.

Selain warga masyarakat dan pengawas LPD dijadikan mitra kerja untuk meningkatkan pertumbuhan, LPD juga mengandeng jasa keuangan yang ada di lingkungan Desa Adat Kedonganan seperti koperasi, BPR dan bahkan sampai para rentenir. Keberhasilan pimpinan LPD menjadikan masyarakat, pengawas dan mitra kerja yang memiliki ruang lingkup usaha sama pada lingkungan Desa Adat Kedonganan menunjukkan masyarakat memiliki pola pikir yang sehat atau baik demi kemajuan LPD itu sendiri. Masyarakat yang sehat, cenderung memiliki jaringan-jaringan sosial yang kokoh. Dalam kehidupan sehari-hari, orang bertemu satu sama lainnya. Pertemuan ini memungkinkan terjadinya inter-relasi yang kental, baik bersifat formal maupun informal (Onyx, 1996).

Jaringan yang dibangun pihak pengelola atau ketua LPD Desa Adat Kedonganan tidak terlepas dari kemampuannya untuk melakukan sebuah komunikasi yang baik dengan pihak-pihak yang mendukung peningkatan kinerja LPD Kedonganan. Komunikasi yang baik diterapkan oleh pihak pimpinan LPD Kedonganan dalam berinteraksi dengan mitra kerja LPD Hal ini diperkuat dengan pendapat yang dikemukakan oleh Putnam (1993) menyatakan bahwa Jaringan adalah infrastruktur dinamis dari modal sosial yang berwujud jaringan-jaringan kerjasama antar manusia atau individu. Jaringan tersebut memfasilitasi terjadinya komunikasi dan interaksi yang memungkinkan tumbuhnya kepercayaan yang memperkuat kerjasama.

Jaringan yang dibangun oleh pihak pimpinan LPD Desa Adat Kedonganan untuk pertumbuhan ekonomi masyarakat jelas tidak didasari atas paksaan maupun menekan 
namun lebih pada pendekatan humanis dengan prinsip kesamaan, kebebasan dan kesukarelaan serta keberadaban. Jaringan akan mampu berjalan dengan baik apabila mampu menerapkan prinsip-prinsip tersebut. Menurut Hasbullah (2006) menyatakan modal sosial tidak hanya dibangun oleh satu individu, melainkan akan terletak pada kecendrungan yang tumbuh dalam satu kelompok masyarakat untuk bersosialisasi dalam wujud partisipasi sebagai bagian penting dari nilai-nilai yang melekat. Artinya modal sosial terletak pada kemampuan sekelompok orang atau masyarakat dalam suatu asosiasi atau perkumpulan dalam melibatkan diri dalam suatu jaringan hubungan sosial. Hubungan sosial ini dilakukan dalam berbagai variasi jalinan sosial yang didasari oleh prinsip kesukarelaan, kesamaan, kebebasan, dan keberadaban.

Kemampuan ketua LPD Desa Adat Kedonganan untuk selalu menyatukan diri dengan masyarakat adat, masyarakat pendatang, prajuru atau pengawas LPD dan para pengusaha yang ada di lingkungan Desa Adat Kedonganan menunjukan ketua LPD mampu membangun modal sosial sangat kuat di masyarakat.

Terlihat jelas bahwa hubungan atau konektivitas yang disediakan oleh jaringan sosial dapat mengurangi 'jarak sosial' antara LPD Desa Adat Kedonganan dengan sesama anggota kelompok usaha sektor jasa keuangan yang ada di lingkungan Desa Adat Kedonganan beserta masyarakat Desa Kedonganan. Sehingga disini terdapat dua hal penentu keberhasilan jarak sosial antara sesama usaha sektor jasa keuangan serta masyarakat yaitu kemudahan komunikasi dan tingkat kepercayan. Dimana, komunikasi menjadi lebih mudah apabila difasilitasi oleh bahasa yang sama atau satu persepsi, budaya dan arus informasi yang efektif. Budaya yang sama mampu terhindar dari aspek kesalahapaham yang terjadi ketika adanya suatu perbedaan dalam nilai-nilai dan keyakinan. Hal terpenting yang dilakukan adalah membangun komunikasi yang efektif dan baik. Sedangkan pada tingkat kepercayaan bagaimana cara untuk mentaati kewajiban atau yang sudah menjadi kesepakatan dalam membangun kontektivitas tersebut.

\section{Membangun Kepercayaan Masyarakat Kedonganan Kepada LPD}

Membangun kepercayaan disaat terjadinya tingkat resistensi masyarakat kepada pengelola LPD Desa Adat Kedonganan sangatlah tidak mudah dilakukan. Dari temuan penelitian mengungkapkan dimana masyarakat memandang sebelah mata pendirian LPD Desa Adat Kedonganan karena sebelumnya terjadi pengelolaan KUD Kedonganan yang 
tidak baik sehingga menyebabkan bangkrut mengakibatkan beberapa asset masyarakat tidak mampu dikembalikan atau hilang. Membangun kepercayaan kepada masyarakat inilah menjadi tugas utama yang harus dilakukan oleh pimpinan atau ketua LPD Desa Adat Kedonganan beserta jajaran pengurus lainnya. Pendapat yang dikemukakan oleh oleh Fukuyama (1995), bahwa kepercayaan itu adalah harapan yang tumbuh di dalam sebuah masyarakat yang ditunjukkan oleh adanya perilaku jujur, teratur dan kerjasama berdasarkan norma-norma yang dianut bersama. Kepercayaan sosial merupakan penerapan terhadap pemahaman ini. Kepercayaan sosial pada dasarnya merupakan produk dari modal sosial yang baik. Adanya modal sosial yang baik ditandai oleh adanya lembagalembaga sosial yang kokoh.

Untuk menjawab berbagai pertanyaan dan ketidakpercayaan masyarakat, Ketua LPD beserta staff dan Prajuru Desa Adat Kedonganan melakukan langkah yang paling utama dengan menerapkan tata kelola yang baik dan didasari atas Dharma mengacu pada Konsep Catur Purusa Artha. Konsep Catur Purusa Artha, yaitu empat tujuan hidup manusia, yakni Dharma, Artha, Kama dam Moksa (Pancadana dan Oka, 2013). Dharma atau kebaikan dijadikan dasar utama oleh Ketua LPD Desa Adat Kedonganan dalam menjalankan kegiatan usahanya, karena dengan mengamalkan dharma atau kebaikan dalam menjalankan kegiatan usahanya diyakini maka Ida Sang Hyang Widhi Wasa akan menganugerahkan berkatnya berupa Artha yang bersumber dari keuntungan berupa bunga dari usaha simpan-pinjam. Selanjutnya pada aspek Kama, bagian dari keinginan atau pemenuhan kebutuhan akan bisa terpenuhi dengan keuntungan yang diperoleh LPD dalam kegiatan usahanya dapat membantu masyarakat dalam hidup bermasyarakat, seperti membantu pendanaan Desa Pakraman dalam melaksanakan pembangunan Desa. Setelah Kama tercapai maka yang terakhir adalah Moksa, dimana kegiatan usaha yang dilakukan oleh LPD Desa Adat Kedonganan mampu membantu perekonomian masyarakat desa, beban kehidupan masyarakat ringan sehingga masyarakat akan merasa lebih senang atau bahagia karena kebutuhannya dapat terpenuhi.

Aspek didalam membangun kepercayaan masyarakat yang dilakukan oleh Ketua LPD Desa Adat Kedonganan menonjolkan pada aspek nilai-nilai religius menjadi tatanan dalam menerapkan tata kelola LPD tersebut. LPD bukanlah usaha yang memiliki sifat sosial ekonomi saja namun hal yang terpenting dibangunnya sebuah LPD oleh Prof. IB. Mantra adalah bagaimana cara membangun ekonomi kerakyakatan berdasarkan atas budaya 
sehingga ada nilai-nilai religius yang terkadung dalam LPD tersebut. Hal ini senada dengan pendapat yang dikemukakan oleh Nurjaya (2011) menyatakan bahwa "Kegiatan usaha LPD merupakan kegiatan usaha yang disamping bersifat sosial-ekonomi juga bersifat kultural-religius.

Temuan penelitian lainnya adalah masyarakat dan Prajuru Desa Adat Kedonganan yang menyatakan bahwa Ketua LPD Desa Adat Kedonganan dalam menjawab kekhawatirkan masyarakat Desa Adat Kedonganan dengan melakukan sebuah renovasi Pura Dalem pada Desa tanpa membebani masyarakat dalam pembiayaan renovasi sumber dari keuntungan LPD. Bukti nyata yang dilakukan oleh pihak pengelola LPD mampu secara perlahan-lahan mengembalikan rasa kepercayaan masyarakat kepada jasa sektor keuangan khususnya LPD Desa Adat Kedonganan (Hasil wawancara dengan Dr. I Made Merta (Pengawas LPD) dan I Wayan Sukadana (Masyarakat Adat Desa Kedonganan) pada tanggal 25 Oktober 2016). Hal ini diperkuat oleh pendapat yang dikemukakan oleh Hasbullah (2006) menyatakan bahwa rasa percaya, adalah suatu bentuk keinginan individu atau kelompok untuk mengambil resiko dalam hubungan-hubungan sosialnya yang didasari oleh perasaan yakin bahwa yang lain akan melakukan sesuatu seperti yang diharapkan dan akan senantiasa bertindak dalam suatu pola tindakan yang saling mendukung. Paling tidak, yang lain tidak akan bertindak merugikan diri dan kelompoknya (Putnam, 1993). Tindakan kolektif yang didasari rasa saling percaya akan meningkatkan partisipasi masyarakat atau kelompok dalam berbagai bentuk dan dimensi, terutama dalam konteks kemajuan bersama.

Dalam meningkatkan tingkat kepercayaan LPD Desa Adat Kedonganan kepada masyarakat, menurut Prajuru atau Pengawas dan Masyarakat Desa Adat Kedonganan menyatakan bahwa pengawas sebagai perwakilan masyarakat adat memilih dan memberikan kepercayaan serta kewenangan penuh untuk melakukan pengawasan agar LPD Desa Adat Kedonganan berjalan dengan baik yang mengacu pada aturan-aturan pengawas tanpa mencampuri mekanisme tata kelola manejemen LPD Desa Adat Kedonganan seperti mengawasi semua aktivas dan praktik tata kelola LPD yang nantinya akan disampaikan kepada masyarakat (Hasil Wawancara dengan Dr. I Made Merta (Pengawas LPD) dan I Wayan Sukadana (Masyarakat Adat Desa Kedonganan) pada tanggal 25 Oktober 2016). Berdasarkan Keputusan Gubernur Bali No: 95/01-C/HK/2003 tanggal 12 Maret 2003 tentang pelimpahan wewenang dan pengawasan Lembaga 
Perkreditan Desa di Provinsi Bali kepada PT Bank Pembangunan Daerah Bali, pengurus LPD dipilih dan dinilai secara kualitatif oleh Desa Adat melalui peparuman atau rapat adat. Sedangkan Suartana (2009:19) menyatakan bahwa peran badan pengawas internal secara aktif mengawasi kebijakan, operasional dan praktik akuntansi dan pelaporan keuangan dan menjadi penghubung antara pengelola dengan auditor eksternal bila diperlukan. Peran badan pengawas internal sebagai pengawas internal sangat strategis, di samping sebagai auditor internal juga sebagai partner yang bersinergi untuk memajukan LPD.

Tata kelola manajemen LPD Desa Adat Kedonganan yang baik mampu dirasakan manfaatnya oleh masyarakat berdampak pada tingkat perputaran perekonomian semakin maju. Kemajuan perekonomian yang dirasakan oleh masyarakat Desa Adat Kedonganan mampu meningkatkan kesejahteraan dan gaya hidup masyarakat. Dalam hal ini Putnam (1993), memberi pernyataan yang menguatkan bahwa modal sosial yang baik akan melahirkan kehidupan masyarakat yang harmonis. Masyarakat Desa Adat Kedonganan secara bersama-sama atau bersatu dan memberikan kontribusi pada peningkatan dan penguatan modal sosial.

\section{Norma-norma LPD dalam Tata Kelola}

Tata kelola Lembaga Perkreditan Desa (LPD) Desa Adat Kedonganan bukanlah pekerjaan yang mudah karena apabila salah dalam pengelolaannya maka akan berakibat fatal kedepannya. Salah satu langkah yang patut dilakukan adalah ketua beserta staf/pegawai harus mampu melihat kondisi dan perkembangan keuangan suatu Lembaga Perkreditan Desa. Adapun acuan yang patut dilakukan atau dipatuhi adalah sebuah norma atau aturan yang berlaku. LPD Desa Adat Kedonganan yang dipayungi oleh awig-awig atau pararem Desa Adat Kedonganan yang masuk kedalam hukum adat. Menurut Nurjaya, wujud hukum adat bagi LPD tiada lain adalah awig-awig atau perarem di masing-masing desa pakraman. Peraturan daerah (perda) yang selama ini menjadi dasar pengaturan LPD merupakan hukum negara, sehingga sudah tidak selaras lagi dengan amanat UU LKM. "Keberadaan perda dan pergub (peraturan gubernur) selama ini yang mengatur LPD dapat disesuaikan. Sejauh ini, perda yang menjadi dasar operasional LPD lebih mengesankan nuansa perbankan. Kenyataannya, LPD ini merupakan lembaga komunitas adat sehingga sangat berbeda dengan perbankan (Situs LPD Kedonganan, diakses pada tanggal 24 Oktober 2016). 
Pendapat yang dikemukakan Ketua LPD Desa Adat Kedonganan (Hasil Wawancara dengan I Ketut Madra, SH., MM tanggal 18 Oktober 2016) dan Prajuru Desa sebagai Pengawas LPD Desa Adat Kedonganan (Hasil Wawancara dengan Dr. I Made Merta tanggal 25 Oktober 2016) menyatakan selain konsep Catur Purusa Artha dijadikan sebuah model penerapan tata kelola LPD hal yang terpenting juga menjadi perhatiannya terhadap kontribusi yang diberikan LPD kepada masyarakat Desa Adat sesuai dalam ajaran Tri Hita Karana, yang terdiri atas Parhyangan, Pawongan, dan Palemahan. Sebagai bentuk tanggung jawab sosial kepada LPD Desa Adat Kedonganan, LPD Desa Adat Kedonganan telah menerapkan bagian dari aturan atau norma dimana norma-norma dapat bersumber dari agama, panduan moral, maupun standar-satandar sekuler. Norma-norma dibangun dan berkembang berdasarkan sejarah bersama di masa lalu dan diterapkan untuk iklim kerjasama. Norma-norma dapat juga merupakan pra-kondisi maupun produk dari kepercayaan sosial (Putnam 1993, Fukuyama 1995).

Filosofi Tri Hita Karana bagi masyarakat Bali pada umumnya dan masyarakat Desa Adat Kedonganan khususnya menekankan dalam proses kehidupan menuju hidup yang sejahtera, dimana diharapkan kita sebagai manusia mampu menjaga keserasian atau harmonisasi hubungan manusia dengan Tuhan/Ida Sang Hyang Widhi Wasa (Parhyangan), manusia dengan alam (Palemahan) dan manusia dengan sesamanya (Pawongan) (Djayastra, 2012; Astawa, 2012; Damayanthi, 2011; Gunawan, 2011) dalam Bagiada dan Darmayasa (2015).

Implementasi LPD Desa Adat Kedonganan terhadap ajaran Tri Hita Karana (THK) yang disampaikan oleh Ketua LPD, Prajuru Desa dan masyarakat Desa Adat dari sisi parahyangan, krama Desa Adat Kedonganan bisa merampungkan renovasi Pura Tri Kahyangan. Dari sisi pawongan, kegiatan ekonomi masyarakat berkembang melalui usaha kafe yang kemudian berdampak pada perkembangan LPD sebagai lembaga keuangan khusus komunitas adat di Desa Adat Kedonganan. Dari sisi palemahan, melalui berbagai kegiatan aksi dan kompetisi yang melibatkan para pengelola kafe dan banjar, seperti lomba kebersihan kafe dan kebersihan banjar, lingkungan Desa Adat Kedonganan bisa tertata dengan baik (Situs LPD Kedonganan, diakses pada tanggal 24 Oktober 2016). Berdasarkan filosofi THK yang secara sadar dan nyata telah diterapkan oleh masyarakat di Bali, maka LPD juga memiliki tanggung jawab sosial pada masyarakat tempat LPD berdiri (Bagiada dan Darmayasa, 2015). Dalam memberikan perhatian dalam 
bidang pembangunan desa bagi LPD sudah tertuang juga dalam Peraturan Daerah Provinsi Bali No.4 Tahun 2012 tentang LPD pasal 22, ayat 1 menjelaskan bahwa salah satu pembagian keuntungan bersih LPD pada akhir tahun pembukuan adalah untuk dana pembangunan desa 20\% dan dana sosial 5\%. Dana yang mampu diberikan oleh LPD Desa Adat Kedonganan sebagai bentuk tanggung jawab sosial pada masyarakat.

LPD Desa Adat Kedonganan secara bersama-sama baik masyarakat, prajuru dan pengelola mampu menjalankan dan mentaati apa yang menjadi aturan sesuai dengan awigawig atau perarem yang menjadi kesepakatan, tujuan bersama. Mengingat pada hakikatnya, norna-norma itu terdiri dari pemahaman-pemahaman, harapan- harapan dan tujuan-tujuan yang diyakini dapat dijalankan bersama oleh sekelompok orang (Suharto, 2007).

Terpenting juga yang dikemukakan oleh Ketua LPD, Prajuru Desa dan Masyarakat Desa Adat Kedonganan adalah norma yang menjadi kesepakatan bersama untuk dipatuhi antara Pengelola LPD Desa Adat Kedonganan, Prajuru dan masyarakat. Jika ada pelanggaran yang terjadi baik dilakukan oleh Pengelola LPD, Prajuru Desa dan Masyarakat Desa Adat Kedonganan sudah sepatutnya menerima sanksi sesuai dengan hukum adat yaitu awig-awig atau perarem yang sudah menjadi kesepakatan bersama. Hasbullah (2006), menyatakan bahwa Norma-norma, adalah sekumpulan aturan yang diharapkan dipatuhi dan diikuti oleh suatu kelompok atau masyarakat dalam suatu entitas sosial tertentu dan ada sanksi sosial yang dikenakan kepada seseorang atau sekelompok masyarakat jika melanggarnya.

Disini akan terlihat betapa kuatnya norma sosial yang diterapkan oleh Desa Adat Kedonganan guna menjaga hubungan antar masyarakat karena akan merangsang kohesifitas sosial yang berdampak positif bagi perkembangan masyarakat, sehingga masyarakat dapat dinyatakan bahwa norma sosial sebagai bagian dari modal sosial.

Sinergisitas LPD Desa Adat Kedonganan dalam meningkatkan perekonomian masyarakat tidak terlepas dari terbangunnya konsep kebersamaan. Kebersamaan bukannya pada mematuhi aturan yang sudah menjadi kesepakatan namun bagaimana cara menjaga secara bersama-sama asset desa berupa LPD agar mampu tumbuh dan berkembang. Peran masyarakat sangat memiliki peran penting untuk pertumbuhan LPD dimana segala transaksi jasa keuangan masyarakat melakukan di LPD dan Pengurus LPD menjaga dengan kepercayaan yang telah diberikan kepada masyarakat dalam mengelola dana 
masyarakat dimana keuntungan dari LPD akan kembalikan juga kepada masyarakat dalam pembangunan desa seperti budaya, adat maupun ekonomi dan Pengawas selalu menjalankan fungsi sebagai monitoring jalannya LPD tanpa melakukan intervensi kepada pengelola LPD. Konsep kebersamaan dibangun akan berdampak pada pertumbuhan perekonomian di Desa Adat Kedonganan, seperti pada model berikut ini.

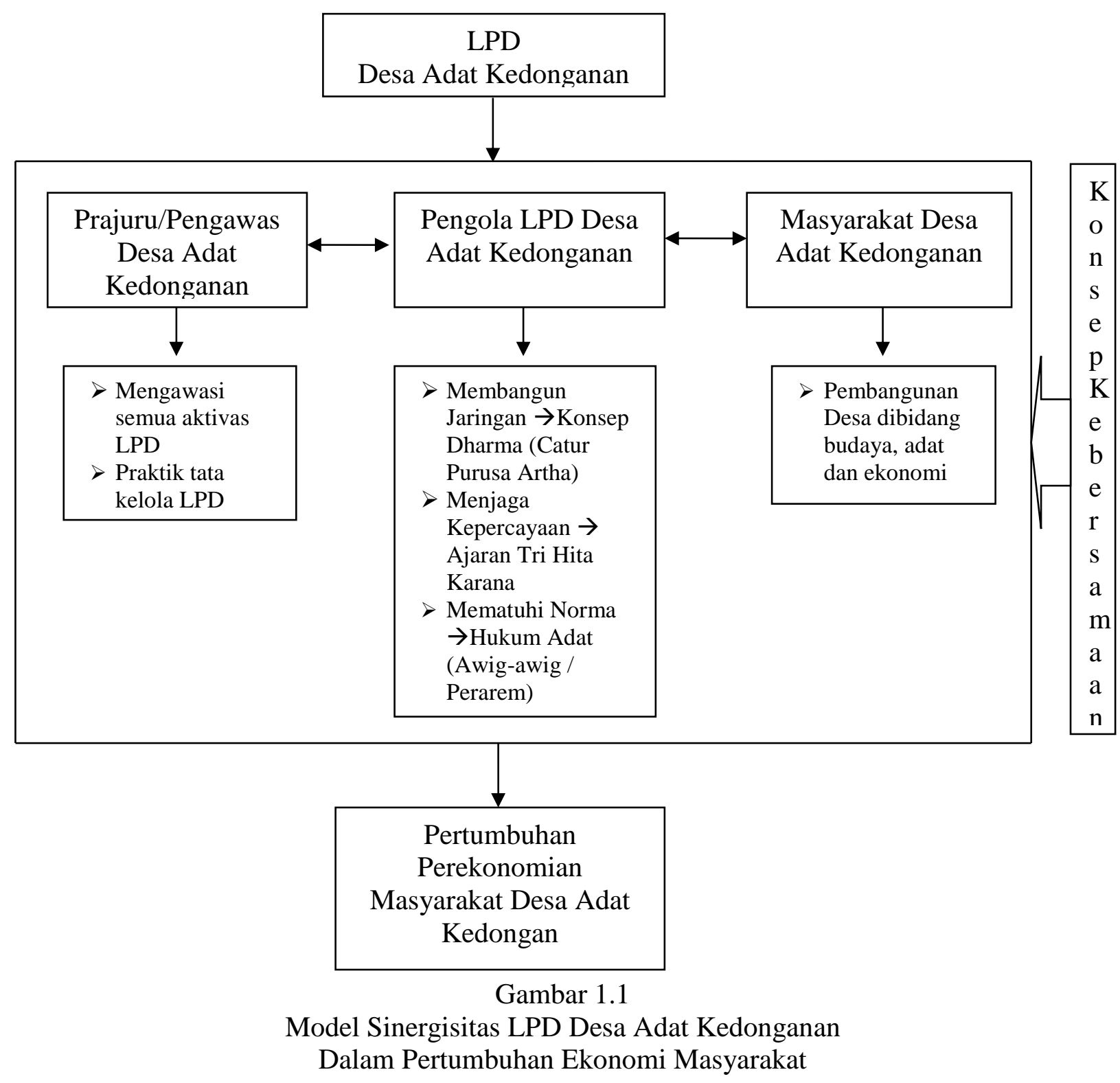




\section{B. Mempertahankan Keunggulan Kompetitif LPD Desa Adat Kedonganan Dalam Meningkatkan Perekonomian Masyarakat}

Mempertahankan sinergisitas yang baik antara pengelola LPD, prajuru adat atau pengawas dan masyarakat Desa Adat Kedonganan bukan hal mudah, untuk mampu LPD Desa Adat Kedonganan mempertahankan sinergisitas hanya dengan mempertahankan keunggulan kompetitif LPD yang memiliki manfat bagi masyarakat Desa Adat Kedonganan baik pada sektor budaya, adat maupun ekonomi. Pengelolaan LPD Desa Adat Kedonganan yang telah berjalan selama dua puluh enam tahun sudah sepatutnya LPD tidak hanya berfikir untuk menciptakan keunggulan kompetitif dalam menghadapi persaingan, tetapi juga bagaimana LPD untuk dapat mempertahankan dan meningkatkan keunggulan kompetitif yang dibuat.

Pendapat yang dikemukakan Corner (1991) terdapat dua model yang saling melengkapi dalam penciptaan keunggulan kompetitif, model pertama adalah model berbasis pasar berfokus pada biaya dan diferensiasi yang berpendapat bahwa perusahaanperusahaan yang tidak efisien atau yang tidak menawarkan produk kepada konsumen yang bersedia membayar harga premium. Teori keunggulan ini terutama didorong oleh faktor eksternal (peluang, ancaman, dan persaingan industri) dan, seperti halnya Porter (1993) menyatakan bahwa mempertahankan keunggulan berarti menyajikan pesaing dengan "target yang bergerak".

Model kedua berpusat pada sumber daya perusahaan dan didorong oleh faktor-faktor yang bersifat internal bagi perusahaan. Sumber daya istimewa yang memberikan keunggulan operasional atau membantu menciptakan posisi pasar yang superior memungkinkan perusahaan untuk menghasilkan pengembalian yang superior. Dalam model teori berbasis sumber daya ini disebutkan bahwa, keberlanjutan keuntungan bergantung pada pesaing yang tidak mampu meniru sumber daya perusahaan.

\section{Faktor Internal LPD}

Keberhasilan kinerja LPD Desa Adat Kedonganan tidak terlepas dari faktor internal yang diuraikan oleh Ketua LPD Desa Adat Kedonganan faktor internal yang terdiri atas tujuan LPD yang mampu dipahami oleh seluruh karyawan, struktur organisasi yang tepat, kualitas sumber daya yang dimiliki LPD dan membangun budaya organisasi sebagai pola kerja LPD. Tujuan akhir dari faktor internal adalah bagaimana dengan memperhatikan 
faktor internal ini mampu meningkatkan kinerja khususnya pada LPD Desa Adat Kedonganan. Menurut Atmosoeprapto, dalam Hessel Nogi (2005: 181) mengemukakan bahwa kinerja organisasi dipengaruhi oleh faktor internal, yang terdiri dari :

1) Tujuan organisasi, yaitu apa yang ingin dicapai dan apa yang ingin diproduksi oleh suatu organisasi.

2) Struktur organisasi, sebagai hasil desain antara fungsi yang akan dijalankan oleh unit organisasi dengan struktur formal yang ada.

3) Sumber Daya manusia, yaitu kualitas dan pengelolaan anggota organisasi sebagai penggerak jalanya organisasi secara keseluruhan.

4) Budaya Organisasi, yaitu gaya dan identitas suatu organisasi dalam pola kerja yang baku dan menjadi citra organisasi yang bersangkutan.

LPD Desa Adat Kedonganan sebagai organisasi sudah tentu memiliki tujuan atau misi yang jelas yaitu "Menjadikan LPD Desa Adat Kedonganan sebagai Lembaga Padruwen (Kekayaan) Desa Adat Kedonganan yang dipercaya dan tangguh sehingga mampu menyangga adat dan budaya Bali" (Situs LPD Kedonganan, diakses pada tanggal 24 Oktober 2016). Pihak pengelola LPD Desa Adat Kedonganan beserta jajarannya (ketua, pengawas dan pengawai) secara bersama-sama membangun satu pemahaman untuk mencapai tujuan atau misi dari LPD. Menurut pendapat yang dikemukakan oleh Wibowo (2007:1) menyatakan bahwa organisasi adalah suatu wadah yang dibentuk untuk mencapai tujuan bersama secara efektif.

Untuk menghindari terjadinya konflik dalam menjalankan tugas para pegawai LPD Desa Adat Kedonganan dimana Ketua LPD beserta bawahannya menyatakan terbentuknya struktur organisasi mampu memperjelas wewenang, tanggung jawab pengelola dalam melaksanakan tugas karena struktur organisasi dapat mengurangi kesimpangsiuran dalam pelaksanaan tugas. Struktur organisasi dapat diartikan sebagai kerangka kerja formal organisasi yang dengan kerangka kerja itu tugas-tugas pekerjaan dibagi-bagi, dikelompokkan, dan dikoordinasikan (Robbins dan Coulter, 2007:284)

Untuk meningkatkan kualitas sumber daya manusia LPD Desa Adat Kedonganan agar mampu bersaing terhadap kompetitor sektor jasa keuangan Ketua LPD Desa Adat Kedonganan selalu melakukan pengembangan sumber daya manusia LPD Desa Adat Kedonganan, agar pengetahuan, kemampuan dan keterampilan para pengelola sesuai dengan tuntutan pekerjaan yang mereka lakukan sehingga mampu meningkatkan kualitas 
pelayanan kepada stakeholder LPD. Menurut Simamora (2006:276) menyatakan bahwa pelatihan bertujuan untuk membekali, meningkatkan, dan mengembangkan kompetensi kerja guna meningkatkan kemampuan, produktivitas dan kesejahteraan. Pengembangan sumber daya manusia bagi pegawai adalah suatu proses belajar dan berlatih secara sistematis untuk meningkatkan kompetensi dan kinerja mereka dalam pekerjaannya sekarang dan menyiapkan diri untuk peran dan tanggung jawab yang akan datang (Ruky, 2006: 227).

LPD Desa Adat Kedonganan dalam menjalankan usahanya yang disampaikan oleh Kepalanya menyatakan bahwa pola pengelolaan yang berbasis komunitas dengan landasan nilai-nilai kekeluargaan dan kegotong-royongan dalam bingkai adat dan budaya Bali, inilah yang menjadi budaya dalam LPD Desa Adat Kedonganan yang tidak terlepas dari konsep awal Prof IB. Mantra membentuk LPD adalah ekonomi kerakyatakan dengan basis budaya bali.

\section{Faktor Eksternal LPD}

Mulyadi (2001; 80) dan Peter Wright (1996;23) dalam Suryanata (2009:35) membagi lingkungan eksternal atau makro atas empat kekuatan pokok : politik dan hukum, ekonomi, teknologi dan sosial.

\section{a. Faktor politik}

Peraturan Daerah (Perda) Provinsi Bali Nomor 4 Tahun 2012 tentang Lembaga Perkreditan Desa (LPD) hingga sekarang masih tetapi menjadi isu politik karena menurut Ketua LPD Desa Adat Kedonganan menyatakan LPD termasuk kedalam lembaga keuangan mikro (LKM) yang telah diatur didalam undang-undang dan LPD tunduk pada hukum Adat Bali. Hal ini diperkuat oleh pendapat yang dikemukakan oleh Nurjaya secara Undang-Undang nomor 1 tahun 2003 tentang Lembaga Keuangan Mikro (LKM) yang mengakui dan melindungi Lembaga Perkreditan Desa (LPD) di Bali sebagai lembaga keuangan bersifat khusus yang diatur hukum adat, sehingga secara aturan kedudukan kepemilikan LPD saat ini sudah jelas milik desa adat. Segala sesuatu terkait dengan dana-dana LPD harus dihasilkan melalui pararem dan meminta persetujuan kepada krama desa (Situs LPD Kedonganan, tanggal akses 24 Oktober 2016).

Isu politik tentang perda diatas tidak berpengaruh signifikan akan penurunan pendapatan LPD, namun kinerja LPD tetap konstan, terlihat masyarakat tidak 
terpengaruh akan isu politik tersebut dan memberikan kepercayaan kepada pengelola dan prajuru atau pengawas yang mengatasi persamalahan tersebut.

\section{b. Faktor Ekonomi}

LPD Desa Adat Kedonganan mampu membangun sektor ekonomi masyarakat yang terlihat dari ditatanya kawasan tepi pantai menjadi kawasan kuliner, pengelolaan pasar ikan dan terbentuknya sektor-sektor ekonomi lainnya seperti jasa penyewaan kendaraan, rumah kost dan sebagainya. Sebagai bentuk antisipasi akan faktor eksternal peran LPD Desa Adat Kedonganan mampu menjadi pengerak ekonomi masyarakat karena seluruh aktivitas yang berkaitan dengan sektor perekonomian di motori oleh LPD. Kepercayaan masyarakat akan tata kelola LPD dalam meningkatkan sektor ekonomi terlihat dari seluruh masyarakat yang ada di wilayah Desa Kedonganan menjadi LPD sebagai sektor jasa transaksi keuangan dari meminjam, menabung dan sebagainya.

\section{c. Faktor Sosial}

Bukti nyata yang dilakukan oleh LPD Desa Adat Kedonganan terlihat dari pembangunan desa baik budaya, adat dan ekonomi. Kinerja LPD Desa Adat Kedonganan yang baik mampu memberikan kebutuhan masyarakat secara merata, peran LPD mampu membangun lingkungan kerja dan kesejahteraan sosial bagi masyarakat Desa Kedonganan. Faktor sosial yang telah direalisasikan dengan baik niscaya mampu memperkuat masyarakat kepada LPD.

\section{d. Faktor teknologi}

Di era globalisasi pihak Pengelola LPD Desa Adat Kedonganan sudah mengantisipasi akan ancaman pada faktor teknologi dimana pelayanan yang diberikan sudah berbasis sistem untuk menghindari terjadinya kecurangan-kecurangan pada pengelola dan membangun transparansi, melakukan kajian-kajian tentang peningkatan LPD guna mampu bersaing pada sektor lembaga keuangan mikro.

Mempertahankan Keunggulan Kompetitif LPD Desa Adat Kedonganan yang dilakukan oleh pihak pengelola LPD dengan memperhatikan faktor internal dan eksternal merupakan wujud nyata pengelola agar LPD tetap mampu bertahan dan lebih maju di masa yang akan datang seperti yang tertuang pada model berikut ini. 


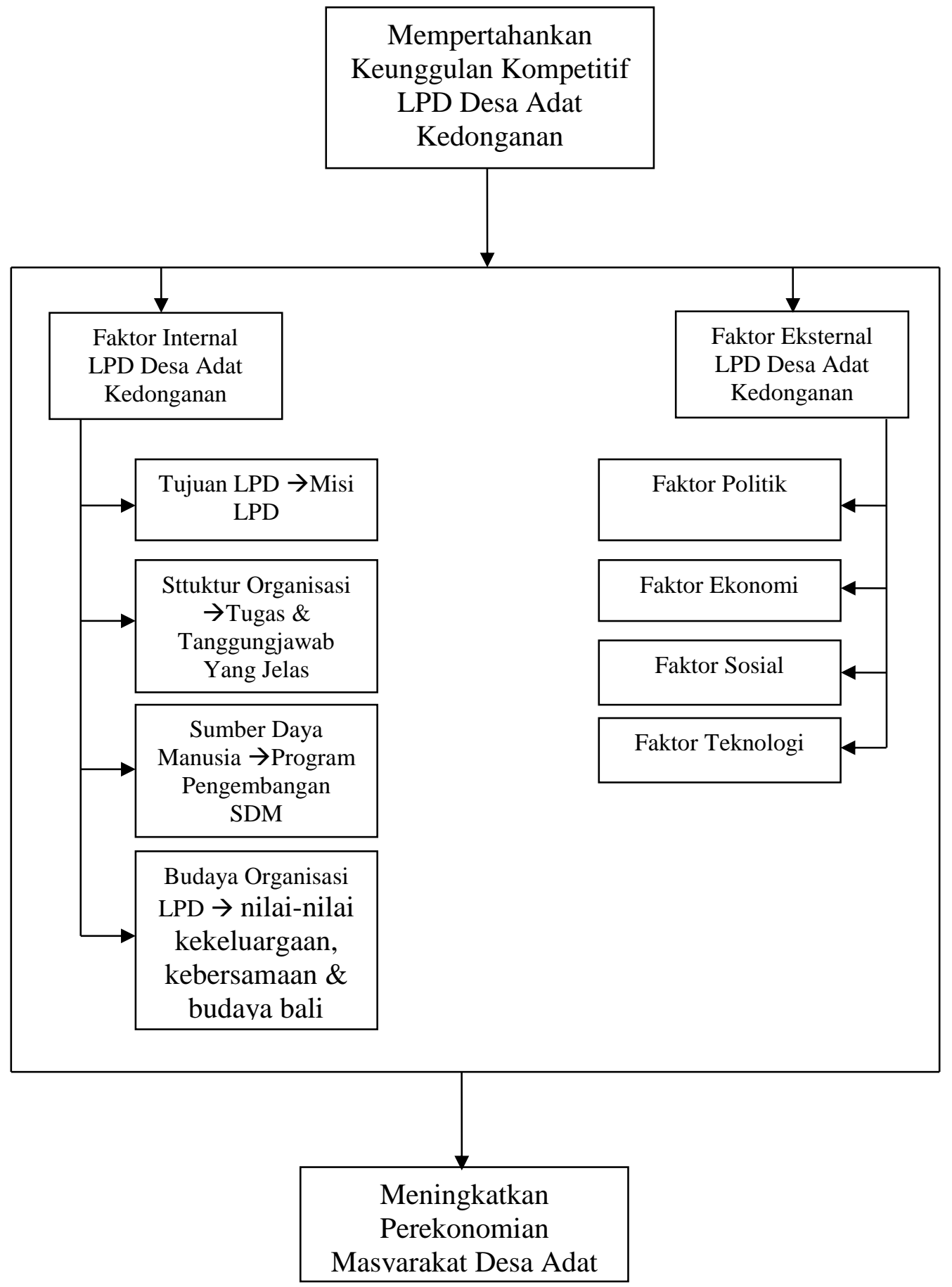

Gambar 1.2

Mempertahankan Keunggulan Kompetitif LPD Desa Adat Kedonganan

Dalam Meningkatkan Perekonomian Masyarakat 


\section{KESIMPULAN}

Dari hasil analisis sinergisitas Lembaga Perkreditasn Desa (LPD) Desa Adat Kedonganan dalam membangun perekeonomian masyarakat Desa Kedonganan dapat disimpulkan bahwa :

a) LPD Desa Adat Kedonganan melakukan sinergisitas bersama dengan Prajuru Desa Adat Kedonganan dan Masyarakat Desa Adat Kedonganan secara bersama-sama untuk membangun perekonomian masyarakat Desa Kedonganan. Dalam melaksanakan sinergisitas menggunakan pendekatan modal sosial dengan aspek :

- Membangun jaringan dengan lembaga keuangan mikro dan makro yang ada di lingkungan Desa Kedonganan yang berlandaskan pada Dharma atau kebaikan konsep Catur Purusa Artha.

- Menjaga kepercayaan, dimana pengelola LPD Desa Adat Kedonganan menciptakan kepercayaan terhadap masyarakat Desa Kedonganan menggunakan ajaran Tri Hita Karana sebagai konsepnya.

- Dalam norma-norma yang digunakan dalam tata kelola LPD Desa Adat Kedonganan mengacu pada hukum adat yaitu awig-awig atau perarem yang sudah menjadi kesepakatan bersama masyarakat adat Desa Kedonganan.

b) Mempertahankan keunggulan kompetitif LPD Desa Adat Kedonganan dalam meningkatkan perekonomian masyarakat pihak pengelola LPD Desa Adat Kedonganan tetap memperhatikan faktor internal atas dan eksternal. Dengan memperhatikan kedua faktor tersebut agar mampu menciptakan tata kelola yang baik didasari atas prinsip modal sosial akan berdampak terhadap meningkatkanya kinerja keuangan LPD. Kinerja LPD yang baik akan berdampak terhadap loyalitas nasabah yang tinggi serta kesejahteraan masyarakat meningkat. Kesejahteraan masyarakat yang baik akan menunjang pertumbuhan ekonomi pada masyarakat Desa Adat Kedonganan. 


\section{DAFTAR PUSTAKA}

Ansoff, H.I. (1968). Corporate Strategy: An Analytic Approach to Business Policy For Growth and Expansion. Penguin Books. Harmondsworth. Middlesex.

Bagiada, I.M., and Darmayasa, I.N. (2015). Implementasi Filosofi Tri Hita Karana Dalam Pengungkapan Tanggungjawab Sosial Pada Lembaga Perkreditan Desa (LPD). Prosiding Simposium Nasional Akuntansi Vokasi ke-4, Manado, 28-30 Mei 2015. Hal. 798-815.

Braun, V., and Clarke, V. (2006). Using Thematis Analysis in Psychology Qualitative Research in Psychology, 3 (2): 77-101. ISSN 1478- 0887.

Coleman, J.S. (1988). Sosial Capital in the Creation of Human Capital, The American Journal of Sociology, 94: S95-S120, Supplement: Organizations and Institution: Sociological and Economic Approaches to the Analysis of Sosial Structure.

Corner. (1991). Pemberdayaan Masyarakat Pedesaan. Jakarta: Bumi Aksara.

Fukuyama, F. (1995). Trust: The Sosial Virtue and The Creation of Properity. New York: Free Press.

Fukuyama, F. (1999). Sosial Capital and Civil Society. The Institute of Publi Policy, George Mason University.

Hasbullah, J. (2006). Sosial Kapital: Menuju Keunggulan Budaya Manusia. Indonesia. Jakarta: MR-United Press.

Hampden-Turner, C. (1990). Charting the Corporate Mind: Graphic Solutions to Business Conflicts. New York: The Free Press.

Hartanto, F.M. (1996). Kepemimpinan Sinergistik: Membangun Keunggulan Melalui Kerjasama dan Aliansi Strategik. Studio Manajemen Jurusan Teknik Industri Institut Teknologi Bandung, Bandung, 2-6.

Hessel, N. (2005). Manajemen Publik. PT. Gramedia Widiasarana.

http://www.lpdkedonganan.com/2014/02/lpd-di-bawah-hukum-adat-perda-pergup.html; diakses: 24 Oktober 2016; pk. 23.15 wita.

http://www.lpdkedonganan.com/2015/04/selae-tiban-sinergi-lpd-kedonganan.html; diakses : 24 Oktober 2016; pk. 23.27 wita.

http://www.lpdkedonganan.com/p/geografi-dan-demograsi-kedonganan.html; diakses : 24 Oktober 2016; pk. 23.33 wita. 
http://www.lpdkedonganan.com/p/visi-dan-misi.html; diakses pada 24 Oktober 2016; pk. 23.50 wita

Keputusan Gubernur Bali No: 95/01-C/HK/2003 tanggal 12 Maret 2003

Mulyana, D. (2001). Metode Penelitian Kualitatif. Bandung: Remaja.

Mulyana, D. (2010). Metodologi Penelitian Kualitatif. Bandung: PT. Remaja. Rosdakarya.

Nurjaya, I.N, et al. (2011). Landasan Teoritik Pengaturan LPD. Denpasar: Udayana University Press.

Onyx, J. (1996). The Measure of Sosial Capital. Paper presented to Auatralian and New Zealand Third Sektor Research Conference on Sosial Cohesion, Justice and Citizenship: Role of Voluntary Sektor. Victoria University.

Pancadana, D.M., and Parwata, A.A.G.O. (2013). Catur Purusa Artha Sebagai Dasar Kegiatan Usaha Lembaga Perkreditan Desa (LPD) Di Desa Pakraman Kikian. Karya Ilmiah. Hukum Bisnis Fakultas Hukum Universitas Udayana.

Peraturan Daerah Provinsi Bali No. 8 Tahun 2002.

Peraturan Daerah Provinsi Bali No. 4 Tahun 2012 tentang Lembaga Perkreditan Desa.

Peraturan Gubernur Bali Nomor 11 Tahun 2013. Tentang Pelimpahan Wewenang dan Pengawasan Lembaga Perkreditan Desa.

Porter, M.E. (1993). Keunggulan Bersaing. ALih Bahasa Agus Dharma, Agus Maulana. Jakarta: PT. Geloga Aksara Pratama.

Putnam, R. (1993). The Prosperous Community; SOSIAL Capital and Public Life, The American Prospect, 13-65-78.

Quigley, M. (1993). A Culture of Synergy, Executive Excellence. 10 (2): 12 - 13.

Riddell, M. (1997). Bringing back balance to policy development. In: Robinson D (ed) Sosial Capital and Policy Development. Wellington: Institute of Policy Studies.

Robbins, S., and Coulter, M. (2007). Manajemen. Edisi Kedelapan. Jakarta: PT Indeks.

Ruky, A.S. (2006). Sumber Daya Manusia Berkualitas. Jakarta: PT. Gramedia Pustaka Utama.

Simamora, H. (2006). Manajemen Sumber Daya Manusia. Edisi 2. STIE YKPN.

Suartana, I.W. (2009). Arsitektur Pengelolaan Risiko Pada Lembaga Perkreditan Desa (LPD). Cetakan Pertama. Denpasar: Udayana University Press.

Suharto, E. (2007). Kebijakan Sosial sebagai Kebijakan Publik. Bandung: Alfabeta. 
Sulasmi, S. (2006). Peran Variabel Perilaku Belajar Inovatif, Intensitas Kerjasama Kelompok, Kebersamaan Visi Dan Rasa Saling Percaya Dalam Membentuk Kualitas Sinergi, Jurnal Ekuitas, 13 (2) Juni 2009: 219 - 237.

Suryanata, I.G.N.P. (2009). Pengaruh Faktor Eksternal Dan Internal Terhadap Kinerja Lembaga Perkreditan Desa (LPD) Serta Dampaknya Bagi Loyalitas Masyarakat Desa (Studi Pada LPD Di Kabupaten Badung Bali). Disertasi. Program Doktor Ilmu Ekonomi. Pascasarajana. Universitas 17 Agustus 1945, Surabaya.

Ward, J., and Peppard, J. (2002). Strategic Planning for Information Systems, 3rd ed. John Wiley \& Sons.

Wibowo. (2007). Manajemen Kinerja. Edisi Kedua. Jakarta: Raja Grafindo Persada.

Wheelen, T.L., Hunger, D.J. (2001). Manajemen Strategis. Terjemahan Julianto Agung. Yogyakarta: Andi. 